\title{
APAKAH SEBUAH IKLAN DAPAT MEMPENGARUHI KONSUMEN BERLANGGANAN TERHADAP RESTORAN HALAL?
}

\author{
Andika Nuraga Budiman', Muhamad Refki Novesar ${ }^{2}$, Hilma Suyana $^{3}$ \\ YARSI University ${ }^{1,2,3}$
}

Email korespondensi: andika.nuraga@yarsi.ac.id ${ }^{1}$

Received: 22 Sept 2020 Reviewed: 25 Sept 2020 Accepted: 12 Oct $2020 \quad$ Published:30 Oct 2020

\begin{abstract}
The investigation of consumer's perception was widely comprehensive. Many advertisements are represented as campaign of enterprises to promote their company. This is depending on the image of restaurant to shape consumer's perception towards halal restaurant. This study was investigating the consumer's perception towards halal restaurant in Bogor. The investigation was accomplished using quantitative method with 100 respondents who live in Bogor. From the factor analysis result was identified by small components which able to be used as clarification for a number of interrelated variables among the advertisement, consumers attitude and subscribing halal restaurant. Analysis result was found that the consumer's attitude does not have major mediating effect towards the relationship between advertisement to be the customer of halal restaurant.
\end{abstract}

Keywords: Advertisement, Consumer's Attitude, Halal Restaurant

\begin{abstract}
ABSTRAK
Investigasi persepsi konsumen sangat luas. Banyak iklan diwakili sebagai kampanye perusahaan untuk mempromosikan perusahaan mereka. Ini tergantung pada citra restoran untuk membuat persepsi konsumen terhadap restoran halal. Studi ini menyelidiki persepsi konsumen terhadap restoran halal di Bogor. Penyelidikan dilakukan dengan metode kuantitatif dengan 100 responden berdasarkan tempat tinggal mereka di Bogor. Hasil analisis dalam penelitian ini sangat bagus. Dari hasil analisis faktor, diidentifikasi komponen kecil yang dapat digunakan sebagai klarifikasi untuk sejumlah variabel yang saling terkait antara iklan, sikap konsumen dan berlangganan restoran halal. Hasil analisis mendapatkan bahwa sikap konsumen tidak memberikan efek mediasi yang besar pada hubungan periklanan dengan berlangganan restoran halal.
\end{abstract}

Kata kunci: Periklanan, Sikap Konsumen, Restoran Halal 


\section{A. PENDAhuluan}

Organisasi saat ini beroperasi di lingkungan yang ditandai dengan perubahan konstan dan peningkatan kompetisi sebagai akibat dari globalisasi. Penelitian terdahulu Zyman dan Brott (2002) menunjukkan bahwa perubahan terbesar di pasar adalah bahwa konsumen memiliki pilihan yang lebih besar berkaitan dengan produk dan layanan dan organisasi-organisasi harus menjadi lebih sadar upaya iklan mereka. Organisasi sekarang melihat iklan sebagai investasi dan cenderung menghargai over-komunikasi dengan consumers, sehingga anggaran yang lebih besar untuk departemen iklan daripada di masa lalu (Zyman dan Brott 2002). Kemajuan teknologi telah disediakan berbagai media baru untuk iklan kepada konsumen dan telah lanjut diperbolehkan untuk organisasi untuk lebih menjangkau konsumen berkaitan dengan frekuensi dan dampak iklan (Du Plessis, Bothma, Jordaan dan Van Heerden, 2003). Kemajuan dalam teknologi, dikombinasikan dengan kebutuhan pasar untuk meningkatkan iklan kepada konsumen, telah menyebabkan fakta bahwa "Iklan di mana-mana" (Cook, 2001). Paparan konstan untuk iklan mungkin menyebabkan konsumen menjadi kebal terhadap iklan. Pengiklan harus lebih kreatif dalam perumusan iklan dan pemilihan media iklan sehingga untuk mendapatkan perhatian dari target pasar mereka (Cappo, 2003).

Iklan dapat diklasifikasikan ke dalam dua kategori: membangun merek dan terarah (Fernandez dan Rosen, 2000; Lohse dan Rosen, 2001). Iklan pembangunan merek identik dengan iklan produk dan biasanya dilihat di media masa tradisional, termasuk TV, radio, majalah, dan surat kabar. Rute komunikasi biasanya satu-ke-banyak dan dirancang untuk menjangkau khalayak ramai dengan menggunakan taktik intrusi yang bertujuan untuk menarik perhatian pengguna. Iklan terarah dirancang untuk membantu calon pembeli menemukan informasi menarik. Rute komunikasi biasanya satu-ke-satu dan diasumsikan bahwa calon pembeli membawanya ke iklan. Selanjutnya, iklan sebagai salah satu atribut ekstrinsik dari restoran halal untuk menyelidiki hubungan terhadap pelanggan pelindung restoran halal.

Pada penelitian Alam dan Sayuti (2011), telah menemukan hasil berupa perhatian terhadap detail dan kualitas sertifikasi halal telah meningkatkan penerimaan Muslim untuk melindungi restoran halal. Hal tersebut telah mendukung sebuah pernyataan dari fenomena dari seorang Muslim yang ingin mengonsumsi produk halal. Mereka sebagai orang beragama Islam akan mencari sebuah informasi dari produk yang telah mereka beli dan mengkonsumsi produk yang 
belum pernah dikonsumsi sebelumnya. Dengan adanya peningkatan kualitas sertifikasi halal, maka seorang Muslim dapat memiliki keamanan yang lebih baik daripada sebelumnya. Hal ini telah didukung oleh sebuah penelitian oleh Bohari, et.al. (2013) yang menyatakan bahwa selayaknya seorang Muslim selalu mencari produk yang telah diedarkan oleh Muslim juga.

Studi - studi menemukan bahwa iklan sangat mempengaruhi seseorang untuk melakukan perilaku mereka dalam menanggapi iklan. Begitu juga selayaknya seorang konsumen mengharapkan adanya sebuah perlindungan sebelum membeli produk atau jasa. Hal ini sama dengan seorang Muslim yang mengharapkan sebuah perlindungan kepadanya sebelum membeli produk atau jasa. Hal ini dapat diimplementasikan kepada seorang Muslim yang telah berlangganan restoran halal dimana Muslim telah diberikan sebuah jaminan atau perlindungan dari iklan yang berkaitan dengan jaminan halal. Sedangkan penelitian terdahulu Olufayo (2012) mengidentifikasikan tentang efek iklan pada sikap berlangganan konsumen terhadap produk baru di Nigeria, penelitian tersebut menunjukkan bahwa adanya sebuah hubungan yang signifikan dari iklan terhadap sikap berlangganan. Sebuah media yang efektif seharusnya telah melalui berbagai evaluasi, menurut tujuan dari periklanan yang telah dipersembahkan di media, dari beberapa media kemungkinan dapat menarik perhatian konsumen terhadap produk, akan tetapi sangat efektif lagi bila sebuah informasi mengenai produk tersebut sangat baik jika hal tersebut datang dari persepsi konsumennya (Hardey, 2012).

Berbagai penelitian terdahulu telah berhasil menginvestigasi dalam bidang periklanan dari produk terhadap persepsi konsumen. Seperti contohnya pada penelitian Ling, et. al (2010) yang telah menginvestigasi sebuah sikap konsumen terhadap iklan di Malaysia. Hasil penelitian mereka telah menemukan semakin tinggi pendidikan konsumen, maka semakin tinggi akan kesadaran iklan dari produk tersebut. Penelitian terdahulu dari Friman (2010) telah menginvestigasi sebuah hubungan sikap konsumen terhadap iklan seluler, yang mana sebuah iklan seluler adalah iklan yang selalu bermunculan di layar seluler genggam. Hasil penelitian menyoroti pentingnya memanfaatkan data pelanggan dalam desain kampanye iklan seluler. Ketika pengiklan seluler memiliki kemungkinan untuk menargetkan kebutuhan aktual pelanggan berdasarkan data pelanggan yang ada, sikap terhadap iklan seluler cenderung positif. Ini menyiratkan bahwa periklanan seluler harus didasarkan pada layanan daripada penjualan. Terakhir dari penelitian Akpan dan Nwankpa (2015) telah berhasil meneliti sebuah pengaruh dari 
iklan Facebook terhadap perilaku pembelian siswa di Universitas Nigerian. Hasil penelitian mereka telah menemukan bahwa target iklan Facebook adalah konsumen di usia muda. Akan tetapi, hasil mereka menunjukkan pengaruh iklan tersebut tidak memiliki pengaruh yang signifikan dari iklan tersebut terhadap perilaku pembelian konsumen.

Berdasarkan dari penelitian terdahulu, maka dapat dinyatakan masih sangat terbatas untuk penelitian yang membahas penelitian yang menginvestigasi iklan dari restoran untuk kosumen berlangganan restoran halal. Dengan demikian penelitian ini telah memiliki tujuan untuk menginvestigasi pengaruh dari sebuah iklan terhadap sikap konsumen untuk berlangganan restoran halal. Di samping itu penelitian ini mengivesitigasi hasil-hasil penelitian terdahulu yang telah mencari hubungan iklan terhadap sikap konsumen dan berlangganan restoran halal.

\section{B. TELAAH PUSTAKA}

Negara Indonesia telah memiliki sebuah peraturan tentang kebijakan beriklan dalam memasarkan produknya seperti yang disampaikan Peraturan Pemerintah Republik Indonesia No. 69 Tahun 1999. Kebutuhan konsumen dalam negeri akan sistem jaminan halal yang kuat secara hukum dan merebaknya tren halal global mendorong lahirnya Undang-Undang Nomor 33 Tahun 2014. Undang-undang tersebut mewajibkan sertifikasi halal bukan sukarela. Pengendaliannya dilakukan dengan pengaturan LPPOM MUI dialihkan ke pengawasan Kementerian Agama melalui Badan Penyelenggara Jaminan Produk halal (BPJPH) / Badan Penjamin Produk halal (Akim, et. al. 2019). Indonesia terkenal dengan sektor perdagangan, hotel, dan restoran yang menyumbang 14,33 persen dari PDB pada tahun 2013 yang merupakan kontributor terbesar ketiga terhadap PDB. Pada 2013 Bank Indonesia (BI) melaporkan bahwa industri perhotelan tumbuh pada tingkat 6,8 persen, sedangkan industri restoran tumbuh sebesar 5,5 persen pada 2012-2013. Pada saat itu industri hotel tumbuh masing-masing 9,4 dan 8,7 persen, sedangkan industri restoran tumbuh pada 4,2 dan 5,2 persen (Wright, 2014).

Di Indonesia, ada Lembaga Penelitian untuk Obat dan Kosmetik Makanan - Majelis Ulama Indonesia (LPPOM-MUI). Sebuah lembaga studi yang didirikan oleh MUI (Majelis Ulama Indonesia) untuk menjalankan fungsi MUI yang melindungi konsumen Muslim dari mengkonsumsi produk makanan halal, obat-obatan, dan kosmetik. Studi Adiningsih (2012) menemukan bahwa bisnis restoran adalah salah satu bisnis yang sangat prospektif di Indonesia. 
Banyak orang harus makan dan peluang untuk tumbuh sejalan dengan pasar di Indonesia dengan diperkenalkannya berbagai restoran di Jakarta ada di Indonesia. Sebagian besar penduduk Jakarta berasal dari sekitar wilayah Jakarta seperti Jakarta, Bogor, Depok, Tangerang, dan Bekasi (JABODETABEK). Ini juga mengakibatkan penyebaran restoran di Jakarta. Banyaknya restoran di JABODETABEK membuat persaingan bisnis restoran semakin tinggi.

Studi yang dilakukan Hussein et, al. (2015) menemukan bahwa konsumen yang memiliki pengalaman baik dengan merek restoran memiliki identitas persepsi yang baik terhadap restoran di Indonesia. Kota-kota di Indonesia telah tumbuh, selain itu revolusi gaya hidup, preferensi, dan kebutuhan akan kenyamanan menghemat waktu semakin meningkat. Fenomena ini akan mendorong konsumen untuk menemukan area perbelanjaan yang memiliki tempat yang aman dan nyaman, juga menyiapkan makanan jauh dari rumah, di toko seperti restoran, dan menyimpan produk seperti makanan dan minuman (Dyck, et. al. 2012). Dari sumber di atas yang telah ditemukan bahwa orang Indonesia masih memiliki kebiasaan sikap yang cenderung percaya begitu saja terhadap restoran yang terletak di tempat umum.

\section{Periklanan}

Iklan dapat diklasifikasikan ke dalam dua kategori: membangun merek dan terarah (Fernandez dan Rosen, 2000; Lohse dan Rosen, 2001). Iklan pembangunan merek identik dengan iklan produk dan biasanya dilihat di media masa tradisional, termasuk TV, radio, majalah, dan surat kabar. Iklan pembangunan merek cenderung berorientasi produk / jasa (atau pengecer) dengan tujuan untuk membangun citra positif dan menciptakan permintaan untuk produk atau layanan yang mengarah pada pembelian akhir (Barrow, 1990; Rosenberg, 1995). Rute komunikasi biasanya satu-ke-banyak dan dirancang untuk menjangkau khalayak ramai dengan menggunakan taktik "intrusi" yang bertujuan menangkap perhatian pengguna. Iklan terarah dirancang untuk membantu pembeli potensial menemukan informasi menarik (Fernandez, 1995). Rute komunikasi biasanya satu-ke-satu dan diasumsikan bahwa calon pembeli membawanya ke iklan. Beriklan dalam hal ini melayani kebutuhan pelanggan.

Penelitian terdahulu mempelajari bahwa hubungan antara iklan dan sikap konsumen menunjukkan bahwa faktor utama mempengaruhi sikap konsumen seperti faktor budaya, kepribadian, dan psikologi konsumen (Rizki, 2007). Lebih lanjut, sikap konsumen sangat penting pada keputusan pembelian dengan mengikuti langkah-langkah mulai dari identifikasi masalah, 
yaitu merasakan tekanan isi dan kepuasan kebutuhan konsumen. Langkah selanjutnya adalah tingkat pencarian informasi produk dan layanan (Setiadi, 2003). Dalam langkah ini, peneliti menemukan bahwa ada hubungan positif yang signifikan antara iklan dan sikap konsumen. Hal ini dikarenakan konsumen cenderung mencari informasi tentang produk yang ingin mereka beli dari toko ritel seperti restoran dan hotel dari iklan mereka.

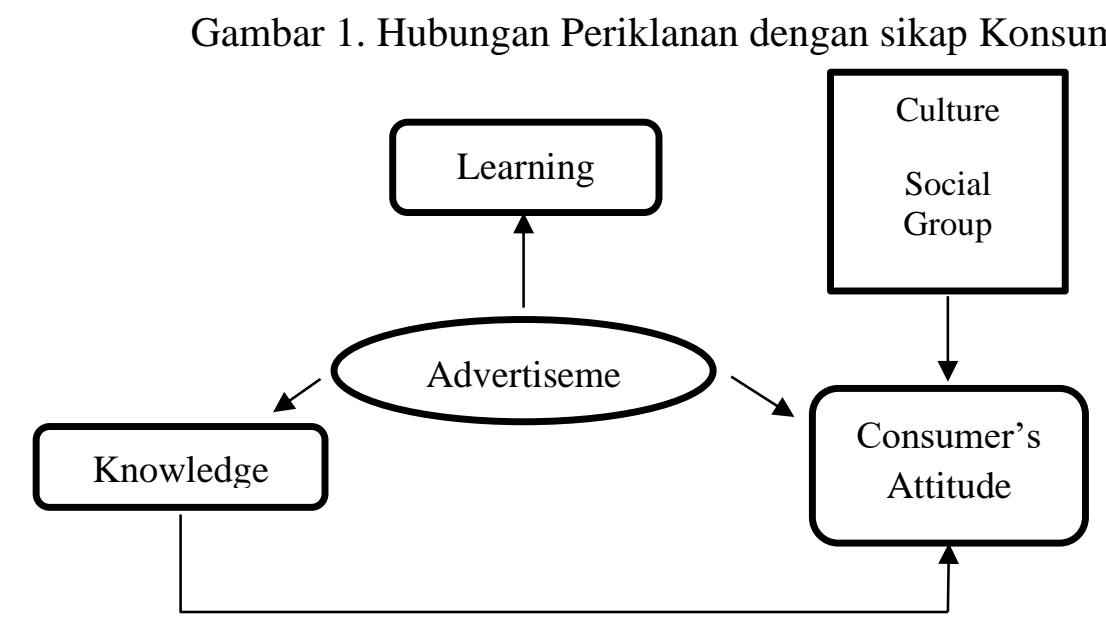

Menurut Ducoffe (1995) dalam penelitian Ling, et la. (2010), ketika informasi iklan digeser melalui kendaraan media tradisional, nilai iklan secara substansial terkait dengan informasi iklan yang informatif. Konsumen selalu ingin memiliki akses instan ke informasi yang mereka cari konten yang mereka gunakan saat ini. Ada kemungkinan bahwa informasi tersebut secara otomatis dikirim ke konsumen (Kaasinen, 2003). Studi seperti Ramaprasad dan Thurwanger (1998); Haghirian dan Madlberger (2005); dan Ducoffe (1996) dalam penelitian Ling (2010), memberikan dukungan bahwa ada hubungan yang kuat dan positif antara sikap informatif dan konsumen terhadap iklan.

\section{Kerangka Teori}

Kerangka kerja penelitian ini didukung oleh Theory of Reasoned Action (TRA) yang dikembangkan oleh (Fishbein dan Ajzen, 1975). Theory of Reasoned Action adalah yang menggunakan pendekatan psikologi sosial untuk melihat faktor penentu perilaku sehat yang dikembangkan oleh Ajzen dan Fishbein. Menurut teori ini, kemauan atau niat seseorang untuk menunjukkan sesuatu perilaku spesifik terkait erat dengan perilaku aktual itu sendiri. Ada dua 
asumsi kunci yang menjadi dasar teori ini adalah perilaku yang mengendalikan pelaku dan manusia itu rasional. Teori "Fishbein-Ajzen" juga menekankan pentingnya peran "niat" atau niat sebagai alasan atau penentu perilaku. Selanjutnya, niat ditentukan dalam penelitian ini.

Gambar 2. Kerangka Penelitian

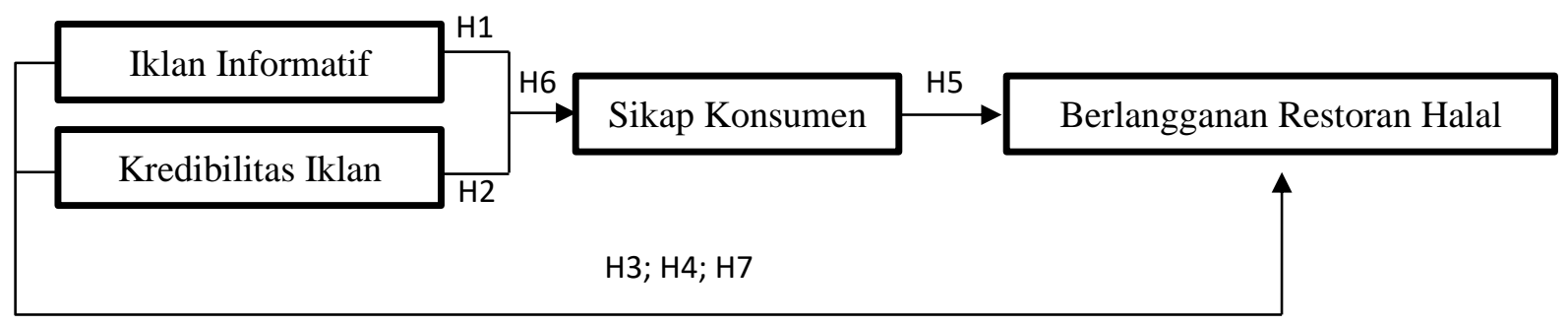

Sebuah kerangka teoritis yang telah dikembangkan berdasarkan teori TRA yang telah dijadikan sebagai landasan teori untuk memperkuat penelitian ini. Kerangka teori ini terdiri dari periklanan yang informatif dan periklanan yang kredibilitas tentang adanya sebuah periklanan tentang halal sertifikasi atau logo halal tertera menjadi sebuah iklan bagi konsumen yang telah melihatnya. Selanjutnya variabel sikap konsumen menjadi variabel penerus dari variabel independen. Rancangan kerangka teoritis ini telah dibentuk menjadi sedemikian rupa sehingga pengembangan variasi krengaka teoritis ini menjadi sederhana dan efektif untuk dianalisis.

Penempatan independen variabel berupa periklanan yang informatif dan kredibilitas iklan berdasarkan peneltian terdahulu. Seperti pada penelitian terdahulu Gerasymenko (2012) menyatakan bahwa iklan yang informatif merupakan sebuah periklanan yang baik, tidak seperti periklanan persuasif yang sebagian besar dikaitkan dengan hal buruk. Akan tetapi penelitian tersebut telah mendapatkan hasil berupa periklanan yang informatif kini sering bertujuan yang bukan untuk memberi sebuah informasi yang berguna bagi konsumen, tetapi untuk mengelola fungsi konsumen individu, yang bertujuan untuk memaksimalkan kesejahteraan periklanan. Penelitian tersebut juga telah membahas bahwa periklanan yang informatif telah kehilangan fitur-fitur sumber informasi pasar dengan cepat. Periklanan sekarang ini lebih memfokuskan kepada mekanisme manipulasi pilihan konsumen yang telah diarahkan pada penciptaan dan penambahan kekuatan pasar pengiklanan. 
Di dunia nyata pembeli membeli informasi harga melalui beberapa cara. Iklan adalah salah satunya. Aspek menarik dari periklan ini adalah perusahaan dapat mengontrol aliran informasi. Penelitian Butters (1977) dalam penelitian Gerasymenko (2012) telah menemukan bahwa pasar yang bersaing secara monopolis memiliki keseimbangan dengan perusahaan yang mengiklankan harga yang berbeda dengan intensitas yang berbeda. Hasil yang menegaskan temuan lain bahwa keseimbangan di pasar dengan pembeli yang memiliki infromasi kurang sempurna ditandai oleh penyebaran harga. Berdasarkan penelitian terdahulu, periklanan yang infromatif adalah sebuah hal yang masih memiliki hasil yang tidak tegas. Periklanan yang informatif memiliki hal yang positif maupun negatif tergantung dari persepektif dari konsumen.

Penelitian terdahulu yang telah dilakukan oleh Verstraten (2015) telah menginvestigasikan kredibiltas iklan melalui brand oriented vs experience oriented terhadap sikap terhadap merek. Hasil yang telah ditemukan olehnya adalah informasi dalam iklan dapat mempengaruhi cara konsumen menerima informasi dan bagaimana cara konsumen menyikapi iklan yang mengandung produk mampun merek yang ditampilkan di iklan (Jaworski \& Maclnnis, 1989). Salah satu faktor dalam menentukan sikap konsumen terhadap iklan maupun merek yang akan mempengaruhi pemrosesan informasi adalah kredibilitas iklan. Sebuah kredibilitas adalah respon konsumen setelah melihat dan memproses pesan iklan.

Berdasarkan penelitian-penelitian terdahulu di atas, maka penelitian ini telah menemukan beberapa hipotesis dari hasil pengamatan terhadap penelitian terdahulu sebagai berikut:

$\mathrm{H}_{1}=$ Adanya pengaruh yang signifikan dari periklanan informatif terhadap sikap konsumen

$\mathrm{H}_{2}=$ Adanya pengaruh yang signifikan dari kredibilitas iklan terhadap sikap konsumen

$\mathrm{H}_{3}=$ Adanya pengaruh yang signifikan dari periklanan informatif terhadap berlangganan restoran halal

$\mathrm{H}_{4}=$ Adanya pengaruh yang signifikan dari kredibilitas iklan terhadap berlangganan restoran halal

$\mathrm{H}_{5}=$ Adanya pengaruh signifikan dari sikap konsumen terhadap berlangganan restoran halal

$\mathrm{H}_{6}=$ Adanya pengaruh signifikan dari periklanan terhadap sikap konsumen

$\mathrm{H}_{7}=$ Adanya pengaruh signifikan dari periklanan terhadap berlangganan restoran halal 


\section{METODOLOGI PENELITIAN}

\section{Target Populasi}

Penelitian ini mengambil sampel berdasarkan convenience sampling yang mana penelitian ini mengambil populasi berdasarkan lokasi dan karakter responden. Lokasi penelitian ini berada di Bogor, yang menjadikan sasaran penelitian ini menargetkan responden yang memiliki kepercayaan sebagai Muslim. Hal tersebut berdasarkan pengetahuan responden terhadap halal menjadikannya sebagai aturan dari kehidupannya. Memiliki aturan dan hukum bahwa seorang yang beragama Islam menuntut dirinya untuk mengonsumsi makanan dan minuman yang halal. Teknik sampling yang digunakan dalam penelitian ini adalah dengan menggunakan penyebaran kuesioner saat pengambilan sampel di lapangan. Kuesioner yang telah digunakan adalah instrumen-instrumen pertanyaan yang telah diadopsi dari penelitian terdahulu, sehingga menjadikan penelitian ini semakin kuat dalam pengambilan datanya. Penggunaan Likert Scale yang tidak memiliki jawaban $\mathrm{N}$ (Netral) bertujuan untuk memaksa responden menjawab jawaban yang tidak bias. Analisis-analisis yang telah digunakan dalam penelitian ini adalah dengan menggunakan analisis faktor, analisis normalitas dan Uji T dalam analisis regresi. Pengujian dalam penelitian ini telah didukung oleh SPSS versi 23.

\section{HASIL DAN PEMBAHASAN}

Dalam penelitian ini, telah menggunakan analisis deskriptif, analisis faktor, dan pengujian hipotesis dengan menggunakan Uji $\mathrm{T}$, serta terakhir dengan menggunakan analisis mediasi. Pengujian analisis dilaksanakan secara 4 tahap. Hasil deskriptif dalam penelitian ini telah didapati responden yang telah memberikan kontribusi untuk penelitian ini. Dari 100 responden sebanyak 19 orang pria dan sisa 81 orang wanita yang telah berkontribusi dalam penelitian ini. Pengambilan data umur responden terdiri dari sebanyak 59 orang yang bersekitar usia 18 - 30 tahun. Sebanyak 23 orang bersekitar usia 31-50 tahun. Sisa 18 orang bersekitar usia 51 tahun ke atas.

Model pengukuran yang meliputi periklanan informatif dan kredibilitas, sikap konsumen dan berlangganan restoran halal dianalisis menggunakan analisis faktor konfirmatori (CFA). CFA mengungkapkan kebutuhan untuk menghapus beberapa item dari konstruksi penelitian karena pemuatan faktor standarnya yang rendah, yang berada di bawah titik batas minimum yang 
direkomendasikan sebesar 0,50. Item yang dihapus adalah sebagai berikut: 1 item dari sikap konsumen (SK1) dan 1 item dari berlangganan restoran halal (BRH 4). Dimana kedua item tersebut tidak dapat memenuhi perwakilan dari variabel-variabel tersebut. Sedangkan sisa 5 item dari sikap konsumen dan 3 item dari berlangganan restoran halal dilanjutkan kepada kontruksi lebih lanjut. Tabel 1 telah mengungkapkan penjelasan analisis faktor dengan menjelaskan MSA (Measure of Sampling Adequacy), communalities, dan pembagian faktor dengan component matrix menjadi 2 komponen.

Tabel 1. MSA (Measure of Sampling Adequacy), communalities, dan component matrix

\begin{tabular}{|c|c|c|c|c|}
\hline Konstruksi & Indikator & $\begin{array}{c}\text { Factor } \\
\text { Loading }\end{array}$ & Commonalities & Alpha \\
\hline \multicolumn{5}{|c|}{ Periklanan yang Informatif } \\
\hline PI1 & Iklan adalah sumber informasi & .911 & .690 & .896 \\
\hline PI2 & Iklan dapat menuntun konsumen & .932 & .526 & \\
\hline $\mathrm{PI} 3$ & Iklan memberikan informasi tepat & .907 & .678 & \\
\hline PI4 & Iklan halal adalah yang dicari & .905 & .869 & \\
\hline \multicolumn{5}{|c|}{ Kredibilitas Iklan } \\
\hline KI1 & Amannya Iklan dengan logo halal & .920 & .830 & .958 \\
\hline $\mathrm{KI} 2$ & Akuratnya Iklan konten halal & .906 & .818 & \\
\hline $\mathrm{KI} 3$ & Fitur terpercaya konten halal & .942 & .854 & \\
\hline KI4 & Promosi konten iklan halal & .891 & .707 & \\
\hline KI5 & Percaya terhadap Iklan halal & .921 & .817 & \\
\hline KI6 & Pentingnya Iklan konten halal & .924 & .787 & \\
\hline \multicolumn{5}{|c|}{ Sikap Konsumen } \\
\hline SK1 & Menariknya Restoran halal & .891 & .429 & .885 \\
\hline SK2 & Restoran halal yang dipercaya & .896 & .587 & \\
\hline SK3 & Amannya Restoran halal & .896 & .657 & \\
\hline SK4 & Bermanfaatnya Restoran halal & .917 & .528 & \\
\hline SK5 & Kesukaan terhadap Restoran halal & .875 & .745 & \\
\hline SK6 & Dapat diterimanya Restoran halal & .865 & .635 & \\
\hline \multicolumn{5}{|c|}{ Berlangganan Restoran halal } \\
\hline BRH1 & Kunjungan Restoran halal & .877 & .540 & .818 \\
\hline BRH2 & Hasrat kunjungan restoran & .886 & .584 & \\
\hline BRH3 & Kunjungan restoran berterusan & .869 & .610 & \\
\hline BRH4 & Rekomendasi restoran & .796 & .448 & \\
\hline
\end{tabular}

Notes: PI - Periklanan yang informatif; KI - Kredibilitas Iklan; SK - Sikap Konsumen; BRH Berlangganan Restoran halal 
Dalam memastikan variabel yang masuk ke dalam kedua komponen adalah periklanan yang informatif dan kredibilitas iklan merupakan komponen 1, sedangkan sikap konsumen dan berlangganan restoran halal adalah komponen 2. Penjelasan dalam 2 komponen ini merupakan pengelompokkan yang ada dalam penelitian ini berdasarkan variabel-variabel yang layak untuk disegmentasikan ke dalam kelompok.

Alfa Cronbach dihitung untuk setiap konstruk, nilainya berkisar antara 0.818 hingga 0.958 . Selanjutnya, nilai alpha keseluruhan menyumbang melebihi nilai rekomendasi yaitu 0.700 (lihat tabel 1). Hasil dari analisis deskriptif dari masing-masing indikator variabel-varibel dijelaskan pada tabel 2 dengan mensandingkan hasil dari uji normalitas dengan menggunakan Skewness dan Kurtosis.

Tabel 2. Statistik Deskriptif dan Uji Normalitas untuk Konstruk Penelitian

\begin{tabular}{|l|l|r|r|r|r|}
\hline \multirow{2}{*}{ Konstruksi } & Item & Mean & $\begin{array}{c}\text { Std. } \\
\text { Deviation }\end{array}$ & Skewness & Kurtosis \\
\hline \multirow{5}{*}{ PI } & PI1 & 3.29 & .715 & -3.448 & 1.347 \\
\cline { 2 - 6 } & PI2 & 3.32 & .709 & -3.726 & 1.715 \\
\cline { 2 - 6 } & PI3 & 3.31 & .706 & -3.630 & 1.709 \\
\cline { 2 - 6 } & PI4 & 3.35 & .730 & -5.352 & 0.485 \\
\hline \multirow{5}{*}{ KI } & KI1 & 3.36 & .732 & -5.448 & 0.531 \\
\cline { 2 - 6 } & KI2 & 3.31 & .800 & -4.585 & 1.473 \\
\cline { 2 - 6 } & KI3 & 3.28 & .683 & -3.352 & 1.480 \\
\cline { 2 - 6 } & KI4 & 3.24 & .767 & -3.535 & 1.452 \\
\cline { 2 - 6 } & KI5 & 3.34 & .741 & -5.186 & 1.012 \\
\cline { 2 - 6 } & KI6 & 3.39 & .737 & -4.654 & 1.190 \\
\hline \multirow{5}{*}{ SK } & SK1 & 3.30 & .595 & -0.854 & -1.209 \\
\cline { 2 - 6 } & SK2 & 3.47 & .540 & -1.124 & -2.369 \\
\cline { 2 - 6 } & SK3 & 3.52 & .522 & -1.240 & -2.987 \\
\cline { 2 - 6 } & SK4 & 3.50 & .522 & -0.900 & -3.075 \\
\cline { 2 - 6 } & SK5 & 3.55 & .539 & -2.481 & -1.776 \\
\cline { 2 - 6 } & SK6 & 3.56 & .519 & -1.933 & -2.690 \\
\hline \multirow{5}{*}{ BRH } & BRH1 & 3.57 & .517 & -2.116 & -2.592 \\
\cline { 2 - 6 } & BRH2 & 3.52 & .522 & -1.240 & -2.985 \\
\cline { 2 - 6 } & BRH3 & 3.32 & .530 & 0.597 & -1.548 \\
\cline { 2 - 6 } & BRH4 & 3.38 & .546 & -0.311 & -1.910 \\
\hline
\end{tabular}

Notes: PI - Periklanan yang informatif; KI - Kredibilitas Iklan; SK -

Sikap Konsumen; BRH - Berlangganan Restoran halal 
Tabel 2 dengan uji normalitas menggunakan Skewness dan Kurtosis untuk penelitian ini. Hasil dari tabel 2 dapat dilihat semua indikator dari kuesioner penelitian ini telah terdistrubusi dengan normal.

Tabel 3. Path Koefisien dan signifikasi

\begin{tabular}{|l|l|r|r|r|r|}
\hline Hipotesis & \multicolumn{1}{|c|}{ Jalur Struktural } & $\begin{array}{c}\text { Path } \\
\text { Koefisien }\end{array}$ & $\begin{array}{c}\text { T } \\
\text { hitung }\end{array}$ & P & Sig. \\
\hline $\mathrm{H}_{1}$ & Perikalan Informatif - Sikap Konsumen & 0.030 & 0.290 & 0.773 & Ditolak \\
\hline $\mathrm{H}_{2}$ & Kredibilitas Iklan - Sikap Konsumen & -0.016 & -0.246 & 0.800 & Ditolak \\
\hline $\mathrm{H}_{3}$ & $\begin{array}{l}\text { Periklanan Informatif - Berlangganan } \\
\text { Restoran halal }\end{array}$ & -0.031 & -0.754 & 0.454 & Ditolak \\
\hline $\mathrm{H}_{4}$ & $\begin{array}{l}\text { Kredibilitas Iklan - Berlangganan } \\
\text { Restoran halal }\end{array}$ & 0.011 & 0.157 & 0.876 & Ditolak \\
\hline $\mathrm{H}_{5}$ & $\begin{array}{l}\text { Sikap Konsumen - Berlangganan } \\
\text { Restoran halal }\end{array}$ & 0.504 & 11.754 & 0.001 & Diterima \\
\hline $\mathrm{H}_{6}$ & Periklanan - Sikap Konsumen & -0.002 & -0.043 & 0.966 & Ditolak \\
\hline $\mathrm{H}_{7}$ & $\begin{array}{l}\text { Periklanan - Berlangganan Restoran } \\
\text { halal }\end{array}$ & -0.011 & -0.408 & 0.684 & Ditolak \\
\hline
\end{tabular}

Tabel 3 telah mendapatkan hasil uji regresi dengan menggunakan uji T secara parsial. Uji seluruh hipotesis dengan uji $\mathrm{T}$ secara berurut mulai dari $\mathrm{H}_{1}(0.290<1.980) ; \mathrm{H}_{2}(-0.246<1.980)$; $\mathrm{H}_{3} \quad(-0.754<1.980) ; \quad \mathrm{H}_{4} \quad(0.157<1.980) ; \quad \mathrm{H}_{5} \quad(11.754>1.980) ; \mathrm{H}_{6} \quad(-0.043<1.980) ; \mathrm{H}_{7} \quad(-$ 0408.<1.980); $\mathrm{H}_{8}(-0.043<1.980)$; dan $\mathrm{H}_{9}(-0.408<1.980)$. Nampaknya hasil uji hipotesis dengan mencari hubungan signifikan antara perikalan dengan sikap konsumen dan berlangganan restoran halal tidak memberikan siginifikasi yang baik. Serta hasil uji mediasi yang menginvestigasi efek mediasi dari sikap konsumen pada hubungan periklanan dengan berlangganan restoran halal tidak memiliki efek mediasi yang besar dibandingan hubungan tanpa efek mediasi

\section{E. KESIMPULAN}

Hasil penelitian ini telah menjawab tujuan penelitian yang menginvestigasi pengaruh iklan terhadap kosumen berlangganan restoran halal. Hasil penelitian menyatakan bahwa iklan tidak memiliki pengaruh kepada konsumen berlangganan restoran halal, melainkan hasil mengenai sikap konsumen. Hasil dari uji hipotesis hanya mendapat sikap konsumen memiliki hubungan signifikan terhadap berlangganan restoran halal. Artinya seorang di Bogor memiliki naluri sikap mereka sebagai konsumen yang selalu percaya bahwa adanya restoran halal di sekitaran lokasi 
umum secara general, mereka berfikir bahwa restoran tersebut memiliki jaminan halal. Hasil ini dapat menyatakan bahwa sebuah periklanan tidak memiliki pengaruh positif terhadap sikap untuk berlangganan restoran halal. Dilihat dari konsumen di Bogor tidak menjadikan sebuah iklan dari restoran halal untuk menstimulasi mereka untuk berlanggan restoran halal. Akan tetapi, hasil dari hubungan sikap konsumen dapat dilihat memiliki kapabilitas sebagai hubungan siginifikan dengan baik. Sebuah periklan (informatif \& kredibilitas) keduanya tidak memiliki hubungan yang siginifikan dengan sikap konsumen dan berlangganan restoran halal, demikian juga hasil dari analisis mediasi yang tidak memiliki efek yang besar.

Periklanan yang infromatif dan kredibilitas iklan tidak memberikan hasil yang positif dikarenakan konsumen di Bogor hanya melihat dari sisi iklan secara kasat mata yang membuat konsumen berfikir merasa cukup hanya melihat dari sisi iklan saja. Penyampaian iklan halal kepada produk non-pangan lebih dilihat oleh kosumen, mungkin saja, hal ini dapat didukung oleh hubungan sikap konsumen dengan berlangganan restoran halal sangat signifikan dalam penelitian ini. Hasil dari penelitian ini diharapkan menjadi sebuah sumber ilmiah yang mendukung pendidikan baik dari pihak instansi maupun lembaga pendidikan lainnya. Penelitian ini merekomendasikan kepada penelitian-penelitian yang akan datang bahwa pengaruh periklanan lebih sesuai dihubungkan dengan produk-produk non-pangan yang lebih menarik perhatian konsumen. Serta penelitian ini merekomendasikan variabel periklanan ini menjadi sebagai tolak ukur untuk penelitian di masa yang mendatang.

\section{DAFTAR PUSTAKA}

Adiningsih, K. P. (2012). Analisis Kepuasan dan Loyalitas Konsumen Restoran Nasi Bebek Ginyo di Jakarta. Master's thesis. Institut Pertanian Bogor.

Akim, A. K., \& N. Purmana (2019). The Shifting of halal Certification System in Indonesia: From Society-Centric To State-Centric. MIMBAR: Jurnal Sosial dan Pembangunan, 35(1), 115-126.

Akpan, C., \& Nwankpa, N. (2015). Influence of Facebook Advertisement on the Buying Behaviour of Students of a Nigerian University. International Journal of Humanities and Social Science, 5(7), 135-148.

Alam, S., \& Sayuti, N. (2011). Applying the Theory of Planned Behavior (TPB) in halal Food Purchasing. International Journal of Commerce and Management, 21(1), 8-20. 
Barrow, P. (1990). Does Your Advertising Direct or Intrude? Canadian Manager 15, 26-27.

Bohari, A. M., Cheng, W. H., \& Fuad, N. W. (2013) An Analysis on The Competitiveness of halal Food Industry in Malaysia: An Approach of SWOT and ICT Strategy. Malaysia Journal of Society and Space, 9(1), 1-11.

Cappo J (2003). The Future of Advertising: New Media, New Clients, New Consumers in the Post-Television Age. New York: McGraw Hill.

Cook G (2001). The discourse of advertising, (Ed.2). New York: Routledge.

Du Plessis, F. Bothma, N, Jordaan Y., \& Van Heerden, N. (2003). Integrated marketing communication. Claremont: New Africa Books.

Dyck, J., Woolverton, A. E., \& Fahwani, Y. R. (2012). Indonesia's Modern Food Retail Sector: Interaction with Changing Food Consumption and Trade Patterns. Economic Information Bulletin Number 97: Department of Agriculture,Economic Research Service.

Fernandez, K. V. (1995). Information Processing in Directional Media: The Effectiveness of Selected Advertising Executional Cues In the Yellow Pages. Dissertation submitted to the School of Business and the Faculty of the Graduate School of the University of Kansas.

Fernandez, K. V., \& Rosen, D. L. (2000). The Effectiveness of Information and Color in Yellow Pages Advertising. Journal Of Advertising, 29(2), 61-73.

Fishbein, M. \& Ajzen, I. (1975). Belief, Attitude, Intention, and Behaviour: An Introduction to Theory and Research. MA: Addison Wesley.

Friman J. (2010). Consumer attitudes toward mobile advertising (Master Thesis). AALTO University School of Economics, Department of Marketing and Management https://aaltodoc.aalto.fi/bitstream/handle/123456789/469/hse_ethesis_12337.pdf?sequence $=1$

Gerasymenko, A. (2012). Informative Advertising: A Market Information Provider or A Seed of Market Power. Journal of Ecoforum, 1(1), 58-63.

Hackley, C. (2010). Advertising \& Promotion: An Integrated Marketing Communications Approach, (Chap.1). London: Sage.

Haghirian, P. \& Madlberger, M. (2005). Consumer Attitude Toward Advertising Via Mobile Devices - An Empirical Investigation Among Austrian Users. Proceedings ECIS (European Conference of Information Systems), Regensburg, Germany.

Hardey, M. (2015). Viewpoint: New Visions: Capturing Digital Data and Market Research. International Journal of Market Research, 54(2), 159-161. doi:10.2501/IJMR$\underline{54-2-159-161}$

Hussein, A., Ismail, T., \& Hapsari R. (2015). The Formation of Brand Loyalty in Indonesian. European Journal of Tourism, Hospitality and Recreation, 6(2), 67-98. 
Jaworski, B. J. \& Maclnnis, D. J. (1989). Information Processing form Advertisements : toward an Integrative Framework. Journal of Marketing.1-23.

Kaasinen, E. (2003). User needs for location-aware mobile services. Personal and Ubiquitous Computing, 7, 70-79.

Ling, K.C., Piew, T.H., \& Chai, L.T. (2010). The Determinants of Consumers' Attitude Towards Advertising. Canadian Social, 6(4), 114-126.

Lohse, G. L., \& Rosen, D. (2001). Signaling Quality and Credibility in Yellow Pages Advertising: The Influence of Color and Graphics on Choice, Journal of Advertising, $30(2), 73-85$.

Nunally, J.C. (1978). Psychometric Theory. New York: McGraw-Hill

Olufayo, T. O. (2012). Effect of Advertising on The Patronage of A New Product. International Journal of Humanities and Social Science, 2(17), 217-225.

Ramaprasad, J., \& Thurwanger, M. L. (1998). South Asian Students Attitudes Toward and Beliefs About Advertising: Measuring Across Cultures. Paper presented at the AEJMC Annual Conference on International Communication Division, Baltimore, MD.

Rizki, N. W. (2007). Pandangan halal Konsumen Ibu Rumah Tangga Terhadap Label halal pada Produk pangan di Kota Tangerang. Institut Pertanian Bogor.

Rosenberg, J. M. (1995). Dictionary of Marketing and Advertising. John Wiley \& Sons, Inc.

Setiadi, N J. (2003). Perilaku Konsumen: Konsep dan Implikasi Untuk Strategi dan Penelitian Pemasaran. Jakarta: Kencana Media.

Verstraten, R. (2015). The Effect of Advertising Credibility: Could It Change Consumers' Attitude and Purchase Intentions?. Master Thesis Economics \& Business. 1-70.

Wright, T (2014). Indonesia Food Service - Hotel Restaurant Institutional Food Service - HRI Report 2014. USA Foregin Agricultural Service.

Zyman S, Brott A (2002). The End of Advertising As We Know It. New Jersey: John Wiley. 